\title{
Evaluation of different treatments of chronic and severe periodontitis in adult patients: meta- analysis of clinical trials
}

\section{Evaluación de diferentes tratamientos de periodontitis crónica y grave en pacientes adultos: metaanálisis de ensayos clínicos}

\author{
Bono Alejandra ${ }^{1}$, Brunotto Mabel $^{2}$, Murúa Julia $^{1}$, Cortes Tamara ${ }^{3}$, Verde Eugenia ${ }^{1}$, Pérez Fernández Nerina ${ }^{4}$ \\ 1. Universidad Nacional de Córdoba, Facultad de Odontología, Departamento Patología Bucal \\ 2. Universidad Nacional de Córdoba, Facultad de Odontología, Departamento Biología Bucal. \\ 3. Universidad Nacional de Córdoba, Biblioteca Facultad de Odontología. \\ 4. Hospital Segundo Taladriz, Servicio de Odontología, La Pampa.
}

\begin{abstract}
Chronic periodontitis is the most frequent type of periodontitis in the population. For its treatment, traditional mechanical methods are applied, such as scraping and root smoothing. Currently, the newest methods that apply antimicrobials, bactericides or lasers are used in combination with traditional methods. The results of clinical trial publications are contradictory about the best therapy to treat chronic periodontitis, so it is necessary to determine the evidence on this subject. The objective of this study was, therefore, to evaluate different treatments for chronic and severe periodontitis in adults through a meta-analysis of clinical trials. This study followed PRISMA guidelines to carry out the meta-analysis of randomized clinical trial studies and MEDLINE, EMBASE, Scielo Cochrane and Scopus databases, between July 30, 2016 and July 30, 2017. The meta-analysis was performed using the standardized mean difference (DME). Heterogeneity was tested using the Q test and the I2 statistic, using the metapackage - R 3.4 .3 (2017). Measurements of insertion loss, depth of probing, bleeding rate and plaque index showed high heterogeneity, therefore the studies were grouped according to the type of treatment patients received (physical or bactericidal methods) for each variable, by what the heterogeneity of some variables decreased
\end{abstract}

KEY WORDS: periodontitis, meta-analysis, treatment

\section{Resumen}

La periodontitis crónica es el tipo más frecuente de periodontitis en la población. Para su tratamiento, se aplican los métodos mecánicos tradicionales, como el raspaje y el alisado radicular. Actualmente, los métodos más nuevos que aplican antimicrobianos, bactericidas o láser, se utilizan en combinación con los métodos tradicionales. Los resultados de las publicaciones de ensayos clínicos son contradictorios acerca de la mejor terapia para tratar la periodontitis crónica, por lo que es necesario determinar la evidencia sobre este tema. El objetivo de este estudio fue, por lo tanto, evaluar diferentes tratamientos para la periodontitis crónica y severa en adultos a través de un metanálisis de ensayos clínicos. Este estudio siguió las pautas PRISMA para llevar a cabo el metanálisis de estudios de ensayos clínicos aleatorizados y bases de datos MEDLINE, EMBASE, Scielo Cochrane y Scopus, entre el 30 de julio de 2016 y el 30 de julio de 2017. El metanálisis se realizó utilizando la diferencia de medias estandarizada (DME). La heterogeneidad se probó mediante la prueba Q y la estadística I2, utilizando el paquete meta R 3.4.3 (2017). Las mediciones de pérdida de inserción, profundidad de sondaje, índice de sangrado e índice de placa mostraron una alta heterogeneidad, por lo tanto se agruparon los estudios según el tipo de tratamiento que recibieron los pacientes (métodos físicos o bactericidas) para cada variable, por lo que la heterogeneidad de algunas variables disminuyó

PALABRAS CLAVE: periodontitis, meta-análisis, tratamiento 


\section{Introduction}

The latest World Health Statistics, issued by the WHO (World Health Organization) in the year 2010, stated that cancer and periodontal disease are among the most common conditions of mankind globally. There is no country or territory in the world that is free of them ${ }^{1,2}$. Periodontal disease is the second most important problem of oral health worldwide and the major cause of tooth loss after the age of 35 years $^{3}$. The WHO Global status report on non-communicable diseases worldwide focused on the need to pay special attention to the elderly; by the year 2050 there will be two billion people over the age of 60 years, of whom $80 \%$ will live in developing countries. Its oral health program will also contribute significantly to the early diagnosis, prevention and treatment of HIV/AIDS, which often manifest in the first place in the form of fungal, bacterial or viral oral infections and injuries 4 .

The term periodontitis includes inflammatory diseases that lead to progressive destruction of the dental support apparatus, affecting the alveolar bone. These pathologies are associated with alteration in the stability of the tooth and mastication, the presence of pain, dental abscesses and, ultimately, with the loss of teeth, manifest impairment and functional disability, and decreased quality of life (American Academy of Periodontology).

Periodontal disease is characterized by periods of rest or inactivity, with few or no symptoms, and periods of flare-ups that occur with loss of insertion and alveolar bone ${ }^{5}$. During progression of the disease, the release of inflammatory mediators increases in all areas of the patient's mouth, both stable and progressive. Although the disease progresses differently in each area because of their specific characteristics, the host response is more global and follows the same pattern in all areas of the interior of the mouth of each individual ${ }^{6}$.

Periodontal diseases are preventable, but it is important to develop intervention strategies that are easy, short-term, viable and low-cost in their implementation. Among the points that should be considered in developing these strategies are the high-risk groups. A careful periodontal diagnosis is of the utmost importance in the subsequent management of the patient's periodontal disease.
The main aim of periodontal treatment is the removal of the subgingival biofilm by the oral route, to achieve homeostasis of the mucosa. The mechanical removal of bacterial deposits from the tooth surfaces, i.e., scaling and root planing (SRP) is the standard treatment. However, bacteria that reside in root concavities, dentin tubules or within soft tissues are not easy to remove with mechanical instrumentation, and therefore SRP rarely leads to the complete elimination of the subgingival biofilm $^{7,8}$. In addition, ineffective reduction of the subgingival microbiota is associated with negative treatment outcomes. For example, the persistence of Actinomycetemcomitans sp., Aggregatibacter $s p ., \quad$ Porphyromonasgingivalis $s p$. and other bacterial species after periodontal treatment has been associated with a destruction of additional tissue $^{9-11}$, while improvement of clinical outcomes has been observed when no such periodontopathogenic bacteria are detected ${ }^{12-14}$.

Taking these limitations into account, the use of SRP combined with antibacterial agents (antibiotics and antiseptics) may be considered a valid therapeutic alternative. The foundation lies in the fact that, after the mechanical disruption of the biofilm through instrumentation, the bacteria become more susceptible to such agents ${ }^{15}$. This conventional non-surgical treatment consists in achieving a reduction of the infection through oral hygiene techniques and scaling and planing sessions carried out by sectors with a weekly frequency.

However, studies indicate the possible translocation of bacteria from one site to another; treatment by quadrants or sextants could thus result in reinfection of previously treated sites from the non-treated ${ }^{16,17}$. In addition, intraoral translocation of these periodontal pathogens would facilitate the immediate re-colonization of recently treated pockets, so that one could hypothesize that, during standard treatment, re-infection occurs prior to completion of the treatment.

From these concepts, there arises a new possibility of therapy called one-stage full-mouth disinfection, comprising scaling and root planing of all quadrants within 24 hours along with adjunctive antiseptic treatments (such as $0.2 \%$ chlorhexidine), that may include rinsing, pocket irrigation, spraying of the tonsils and tongue brushing ${ }^{18,19}$. The protocol consists in: 
- Scaling and root planing the entire mouth within 24 hours ( 2 consecutive sessions).

- Rinse mouth with $0.2 \%$ chlorhexidine solution during the treatment and up to two months after completing the scaling and planing procedure $^{20}$, (with the aim of reducing the number of bacteria in saliva, tongue, mucosa and tonsils to retard the recolonization of the pockets)

- Subgingival irrigations: 3 applications in 10 minutes in all the pockets with $1 \%$ chlorhexidine gel to eliminate any residual bacteria.

- Brushing the tongue with $1 \%$ chlorhexidine gel for 1 minute.

- Several studies have reported clinical and microbiological benefits in patients with severe periodontitis who were treated by one-stage full-mouth disinfection ${ }^{21}$. Other authors have introduced antibiotics such as azithromycin to the protocol, but without satisfactory results ${ }^{22}$.

At the Catholic University of Leuven, Bailen et al. $^{23}$ evaluated the long-term microbiological effects of full-mouth disinfection procedures in 10 patients with chronic severe periodontitis; the study group underwent the protocol of full-mouth disinfection described above, while the control group received scaling and root planing and oral hygiene instructions. The authors concluded that the full-mouth disinfection treatment provides a microbiologically significant improvement at two months compared to those who received conventional periodontal treatment.

In 2005, Koshy et al. $^{24}$ published a study evaluating the results obtained by periodontal treatment with instrumentation ultrasonic only. They evaluated ultrasonic debridement by quadrants, ultrasonic debridement in a single visit and ultrasonic debridement in a single visit using povidone-iodine as a refrigerant. The patients of the latter group were advised to make rinses with chlorhexidine twice a day for a month. All three treatments were equally effective, as all the groups showed clinically significant improvement and there were no differences in the detection of periodontal pathogens in plaque and saliva.

In the research reviewed, we observe that none is conclusive with respect to the microbiological benefit or to the lasting decrease of periodontal pathogens, with the exception of Sigusch et al. ${ }^{25}$, who used systemic metronidazole and full-mouth planing, in contrast to our own results ${ }^{26}$ which showed no statistically significant differences. Other authors found few differences and suggest further studies ${ }^{27}$.

Accurate diagnosis is the first step toward the development of an appropriate treatment plan that would reduce the future risk of periodontal damage and probably lead to resolution of the infection.

Currently, the treatment plan for patients presenting with different types of periodontitis is made on the personal experience of each dental professional, with no scientific basis ${ }^{28}$. The aim of this study was therefore to evaluate different treatments for chronic and severe periodontitis in adults through a meta-analysis of clinical trials.

\section{Methods}

The study was performed according to PRISMA guidelines $^{29}$. It was realized a meta-analysis of randomized clinical trials by MEDLINE, Scielo and Cochrane data base. The selected papers were measured Plaque Index (PI), bleeding index (BI), probing depth (PD) and attachment loss (AL) in control and cases groups of adults subjects, between 30 July 2016 and 30 July 2017.

The meta-analysis was performed by standardized average differences (SME). The heterogeneity was evaluated through $\mathrm{Q}$ test and I2. Packages meta and metafor of R 3.4.3 (2017) was used.

\begin{tabular}{|l|l|}
\hline Inclusion criteria & Randomized controlled trials. \\
\hline Study design & $\begin{array}{l}\text { Participants: patients with diagnosed } \\
\text { periodontitis with the periodontal disease } \\
\text { classification system of the American } \\
\text { Academy of Periodontology criteria. }\end{array}$ \\
\hline Outcome & $\begin{array}{l}\text { Intervention: Subjects assigned to the } \\
\text { experimental or control group with non- } \\
\text { surgical periodontal treatment. }\end{array}$ \\
\hline Exclusion criteria & $\begin{array}{l}\text { Results: reduction of PI, BI, PD and AL. } \\
3 \text { months of follow-up articles, cohort studies, clinical } \\
\text { cases, descriptive studies, opinion } \\
\text { articles, letters or summaries. } \\
\text { Studies in animals. } \\
\text { The studies that recruited participants } \\
\text { with systemic disease or under any } \\
\text { medical treatment that could have an } \\
\text { influence on the periodontal treatment. }\end{array}$ \\
\hline
\end{tabular}




\section{Data Analysis}

The Mantel-Haenszel method and the Peto method were used to estimate the fixed and random effects, since it is the type of binary analyzed result, related to statistical tests of Odds ratio, relative risk or risk difference.

The program $\mathrm{R}$ version 2.10.1 (www.rproject.org), package meta function metabin will be used.

To evaluate the heterogeneity, the Q test will be used. This is calculated by adding the squared deviations of the estimate of the effect of each study, the estimation of the overall effect, the weighting of the contribution of each study by the inverse of its variance Under the hypothesis of homogeneity between effect sizes, the Q statistic follows a Chi-square distribution with $\mathrm{k}-1$ degrees of freedom, with $\mathrm{k}$ being the number of studies. Not rejecting the homogeneity hypothesis usually leads the meta-analyst to adopt a fixed-effects model, because it is assumed that the estimated effect size is only differentiated by the sampling error. Conversely, the rejection of the homogeneity hypothesis can lead to the application of a random effects model, which includes the variability both "within" and "between" the studies ${ }^{30-32}$.

\section{Results}

The Fig. 1 shows chart flow of PRISMA.

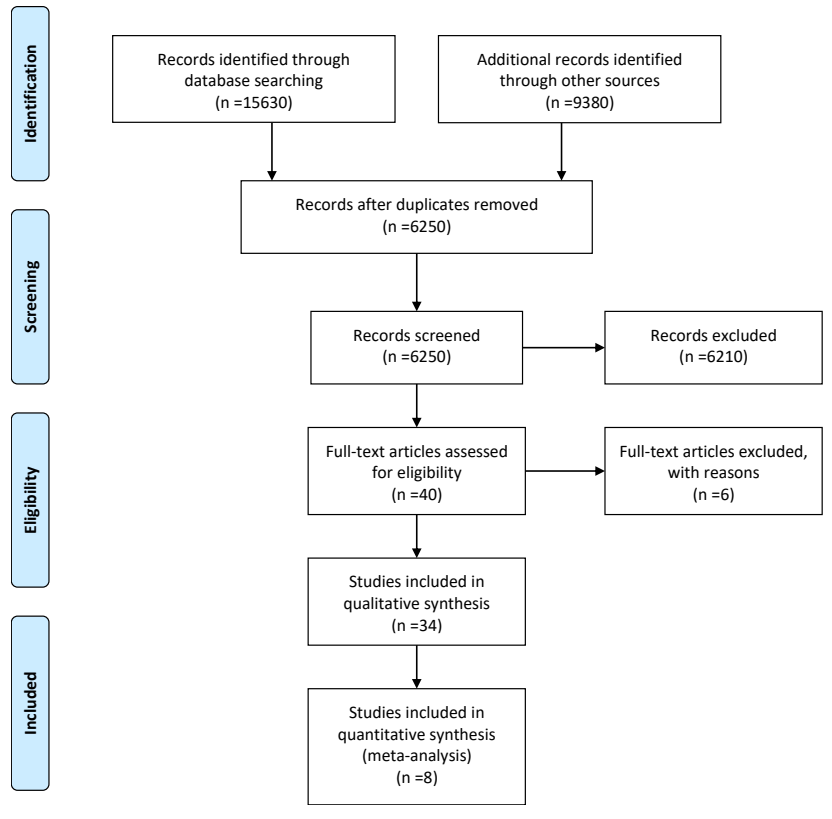

Figure 1. PRISMA chart flow

Table 1 presents characteristics of studies. All the studies were treatment with scaling and smoothing technique. The measurements of PI, BI, PD and AL showed a high heterogenity (Fig.2). The treatments were splitted into differents treatments methods. Eight different kinds of treatments were analyzed. The studies were grouped according to the type of treatment the patients received (physical or bactericidal methods), so the heterogeneity of some variables decreased (Fig. 2).

Table 1. Characteristics of included studies.

\begin{tabular}{|c|c|c|c|c|c|}
\hline Study & Country & $\begin{array}{l}\text { Kind } \\
\text { treat. }\end{array}$ & $\begin{array}{l}\text { Additional } \\
\text { treatment }\end{array}$ & $\begin{array}{l}\text { Age } \\
\text { range }\end{array}$ & $\begin{array}{l}\text { Num. } \\
\text { patient } \\
\text { s }\end{array}$ \\
\hline $\begin{array}{l}\text { Pradeep } \\
\text { et } \\
\text { al.2016 }\end{array}$ & India & $\begin{array}{l}\text { Bacteri } \\
\text { cide }\end{array}$ & $\begin{array}{l}1,2 \% \\
\text { rosuvastatin } \\
\text { e gel }\end{array}$ & $25-45$ & 30 \\
\hline $\begin{array}{l}\text { Pradeep } \\
\text { et } \\
\text { al.2016 }\end{array}$ & India & $\begin{array}{l}\text { Bacteri } \\
\text { cide }\end{array}$ & $\begin{array}{l}1,2 \% \\
\text { atorvastatin } \\
\text { gel }\end{array}$ & $25-45$ & 30 \\
\hline $\begin{array}{l}\text { Dilsiz } \\
\text { A, Cana } \\
\text { kci } \\
\text { V, Aydin } \\
\text { T. } 2013\end{array}$ & Turkish & Physic & $\begin{array}{l}\text { fotodinamic } \\
\text { therapy } \\
\text { potassium- } \\
\text { titanyl- } \\
\text { phosphate } \\
\text { baseline }\end{array}$ & $30-58$ & 24 \\
\hline Dilsiz & Turkish & Physic & Laser & $30-58$ & 24 \\
\hline
\end{tabular}




\begin{tabular}{|c|c|c|c|c|c|}
\hline $\begin{array}{l}\text { A, Cana } \\
\text { kci } \\
\text { V, Aydin } \\
\text { T. } 2013\end{array}$ & & & $\begin{array}{l}\text { potassium- } \\
\text { titanyl- } \\
\text { phosphate } \\
\text { baseline }\end{array}$ & & \\
\hline $\begin{array}{l}\text { Hugar et } \\
\text { al.2016 }\end{array}$ & India & $\begin{array}{l}\text { Bacteri } \\
\text { cide }\end{array}$ & $\begin{array}{l}0.2 \% \text { gel de } \\
\text { clorhexidine }\end{array}$ & $25-50$ & 30 \\
\hline $\begin{array}{l}\text { Hugar et } \\
\text { al.2016 }\end{array}$ & India & $\begin{array}{l}\text { Bacteri } \\
\text { cide }\end{array}$ & $\begin{array}{l}2 \% \\
\text { curcumine } \\
\text { gel }\end{array}$ & $25-50$ & 30 \\
\hline $\begin{array}{l}\text { Jose } \\
\text { Kachapil } \\
\text { lyArun } \\
\text { et al. } \\
2016 \\
\end{array}$ & India & $\begin{array}{l}\text { Bacteri } \\
\text { cide }\end{array}$ & clorhex chip & $30-60$ & 15 \\
\hline $\begin{array}{l}\text { Jose } \\
\text { Kachapil } \\
\text { lyArun } \\
\text { et al. } \\
2016 \\
\end{array}$ & India & Physic & $\begin{array}{ll}\text { diode laser } \\
\text { plus chip } \\
\text { clorhex }\end{array}$ & $30-60$ & 15 \\
\hline
\end{tabular}

\section{DISCUSSION AND CONCLUSION}

Our results show that the plaque index (PI) improved with the traditional scaling and root planing (SRP) method, while the bleeding index (BI) improved with the physical methods. We found great heterogeneity in the comparative studies, of patients included, follow-up time, different drugs and treatments carried out.

Hugar et al. ${ }^{33}$ evaluated the effectiveness of the subgingival application of chlorhexidine gel and curcumin gel as an adjunct to scaling and root planing in the treatment of mild to moderate (4-6 $\mathrm{mm}$ ) periodontal pockets and found that both have an anti-inflammatory effect on periodontal pockets in patients with chronic periodontitis. These results are similar to those reported in multicenter clinical trials by Killoy ${ }^{34}$, Soskolne et al. ${ }^{35}$, Jeffcoat et al. ${ }^{36}$ and Paolantonio et al. ${ }^{37}$, who applied CHX locally and significantly reduced the plaque index, bleeding on probing, depth on probing, and gain in CAL scores, despite no differences being found in gingival inflammation scores between the test and control sites at the start of the study. Soskolne et al. ${ }^{35}$, Jeffcoat et al. $^{36}$ and Heasman et al. $^{38}$, in agreement with our studies, found that the gingival index was significantly reduced in the test and control sites from baseline to the end of the 3 months. However, this reduction could be attributed to conventional therapy (SRP), and the training of the patients and their motivation, as they are monitored throughout the study.
Dilsiz et al. $2013^{39}$ evaluated and clinically compared the clinical effects of the potassiumtitanyl-phosphate (KTP) laser and photodynamic therapy (PDT) for the treatment of chronic periodontitis. Both their treatments showed significant improvements in terms of reduction of BOP and PD and CAL gain compared with initial values $(\mathrm{P}<0.05)$. The laser group, which also included scaling and planing, showed a greater reduction in $\mathrm{PD}$ and more $\mathrm{CAL}$ gain than the other groups $(\mathrm{P}<0.05)$. Y. Cheng ${ }^{40}$ found the same results with adjunctive laser therapy in the reduction of $\mathrm{PD}$ and bleeding on probing (BOP) in a relatively short period of time (3 months), without any adverse effect, which indicates a decrease of the disease. In terms of CAL gain, they found sufficient evidence to demonstrate that combining traditional therapy with laser is more effective.

Pradeep et al. $2016^{41}$ put forward statins as an important group of hypolipidemic drugs that modulate inflammation and alveolar bone loss. Rosuvastatin (RSV) and atorvastatin (ATV) inhibit osteoclastic bone resorption and have osteostimulating properties. They evaluated and compared the efficacy of $1.2 \% \mathrm{RSV}$ and $1.2 \%$ ATV gel locally (LDD) in addition to scaling and root planing (SRP), for the treatment of patients with chronic periodontitis. The three groups showed a significant reduction in the index of bacterial plaque. The improvements in these parameters were significantly higher with sustained release rosuvastatin gels at 6 and 9 months, always as an adjunct to mechanical periodontal therapy. Another study by Cosgarea ${ }^{42}$ shows that an antibiotic regimen for 3 or 7 days adjunctive to SRP had better clinical results than those obtained by SRP alone. The evidence supports the adjunctive use of local antimicrobials with subgingival debridement at deep or recurring periodontal sites, mainly with the use of sustained release antimicrobial vehicles ${ }^{43}$.

Unlike the other authors, Jose et al. 2016 ${ }^{44}$ compared the effects of a laser diode and a chlorhexidine chip used alone and in combination with scaling and root planing in the management of chronic periodontitis. After treatment, the test and control sites showed a statistically significant reduction in PI, GI and pocket depth (PPD). The differences in PD reduction and CAL gain between the control group and the CHX chip and the 
combination groups were statistically significant ( $\mathrm{p}$ $<0.05$ ) at three months, while the diode laser group showed no significant differences with respect to the control group. They confirmed that the local administration of chlorhexidine alone or in combination with diode laser decontamination is effective in reducing pocket depth and improving clinical insertion levels when it is also used as an adjunct to scaling and root planing in non-surgical periodontal therapy in patients with chronic periodontitis.

Similarly, Alwaeli HA found a significant reduction in $\mathrm{PD}$ and $\mathrm{BOP}$, and a significant $\mathrm{CAL}$ gain from the beginning, as well as a significantly greater reduction and gain for SRP + adjunct photodynamic antimicrobial therapy than for SRP at the different times studied. There were no adverse effects of adjunct photodynamic antimicrobial therapy ${ }^{45}$.

We evaluated the quality of the evidence for each comparison and found it "low" because of design limitations that lead to risk of bias, and due to the small number of trials and participants, which leads to imprecision in the effect estimates. We also found great heterogeneity in the choice of treatment.

The published literature describes the clinical evidence for the treatment of chronic periodontitis, which continues to be based in all cases on choosing scaling and root planning treatment as a primary therapeutic measure and then various adjunctive treatments whether physical, chemical or bacteriological, all with statistically significant results. However, more clinical studies are still needed to reach the clinical relevance applicable to a clinical protocol.

\section{Conclusion}

This meta-analysis shows the need to develop studies with standardized results so that they can be integrated in both clinical and research settings. Studies are also needed with a larger number of patients and long-term follow-up to confirm these findings.

In clinical practice, the decision for one nonsurgical periodontal treatment rather than another should include both the patient and the appropriateness of the treatment plan designed.

\section{Acknowledgments}

This work was carried out under the support of the Secretariat of Science and Technology of the National University of Córdoba, Argentina (SECYT-UNC N 411/18).

Todos los autores declaran que no existen conflictos potenciales de interés con respecto a la autoría y / o publicación de este artículo.

All authors declare no potential conflicts of interest with respect to the authorship and/or publication of this article

\section{References}

1. Petersen PE, Ogawa H. Global oral health program, World Health Organization, Geneva, Switzerland. Strengthening the prevention of periodontal disease: The WHO Approach, Geneva, Switzerland, 2010.

2. Petersen PE. Tobacco and oral health the role of the world health organization. Oral Health Prev Dent. 2003;1(4):309-15

3. Bono A. Meta- Análisis de ensayos clínicos sobre aplicación de amoxicilina y/o metronidazol en la terapéutica de la periodontitis crónica. Tesis doctoral. Universidad Nacional de Córdoba, 2010. Disponible en: https://rdu.unc.edu.ar/handle/11086/1319?localeattribute $=$ en

4. Global status report on non-communicable diseases, 2014. OMS.

5. Goodson JM, Tanner AC, Haffajee AD, Sornberger GC, Socransky SS. Patterns of progression and regression of advanced destructive periodontal disease. J Clin Periodontol. 1982 Nov;9(6):472-81

6. Tanner A, Kent R, Maiden MF, Taubman MA. Clinical, microbiological and immunological profile of healthy, gingivitis and putative active periodontal subjects. J Periodontal Res. 1996 Apr;31(3):195-204

7. Cugini MA, Haffajee AD, Smith C, Kent RL Jr, Socransky SS. The effect of scaling and root planing on the clinical and microbiological parameters of periodontal diseases: 12-month results. J Clin Periodontol. 2000 Jan;27(1):30-6.

8. Carvalho LH, D'Avila GB, Leão A, Gonçalves C, Haffajee AD, Socransky SS, Feres M. Scaling and root planing, systemic metronidazole and professional plaque removal in the treatment of chronic periodontitis in a Brazilian population II--microbiological results. J Clin Periodontol. 2005 Apr;32(4):406-11.

9. Renvert S, Wikström M, Dahlén G, Slots J, Egelberg J. On the inability of root debridement and periodontal surgery to eliminate Actinobacillus 
actinomycetemcomitans from periodontal pockets. J Clin Periodontol. 1990 Jul;17(6):351-5.

10. Mombelli A, Gmür R, Gobbi C, Lang NP. Actinobacillus actinomycetemcomitans in adult periodontitis. II. Characterization of isolated strains and effect of mechanical periodontal treatment. J Periodontol. 1994 Sep;65(9):827-34.

11. Mombelli A, Schmid B, Rutar A, Lang NP. Persistence patterns of Porphyromonas gingivalis, Prevotella intermedia/nigrescens, and Actinobacillus actinomyetemcomitans after mechanical therapy of periodontal disease. J Periodontol. 2000 Jan;71(1):14-21.

12. Machtei EE, Dunford R, Grossi SG, Genco RJ. Cumulative nature of periodontal attachment loss. J Periodontal Res. 1994 Sep;29(5):361-4.

13. Socransky SS, Haffajee AD. Evidence of bacterial etiology: a historical perspective. Periodontol 2000. 1994 Jun;5:7-25.

14. Dahlén G, Wikström $M$, Renvert S. Treatment of periodontal disease based on microbiological diagnosis. A 5-year follow-up on individual patterns. J Periodontol. 1996 Sep;67(9):879-87.

15. Marsh PD. Dental plaque: biological significance of a biofilm and community life-style. J Clin Periodontol. 2005;32 Suppl 6:7-15.

16. Peterson BW, He Y, Ren Y, et al. Viscoelasticity of biofilms and their recalcitrance to mechanical and chemical challenges. Kjelleberg $\mathrm{S}$, ed. FEMS Microbiology Reviews. 2015;39(2):234-245.

17. Van Winkelhoff AJ, Van del Velden U, de Graaff J. Microbial succession in recolonizing deep periodontal pockets after a single course of supra-and subgingival debridement. J Clin Periodontol. 1988; 15: 116-22.

18. Preus HR, Gjermo P, Baelum V. A double-masked randomized clinical trial (RCT) comparing four periodontitis treatment strategies: 5-year clinical results. J Clin Periodontol. 2017 Oct;44(10):1029-1038.

19. Quirynen M, Bollen CML, Vandekerckhove BNA, Dekeyser C, Papaioannouw, Eyssen H. FuI/-versus partialmoulh disinfection in the treatment of periodontal infections: short-term clinical and microbiological observations. J Dent Res. 1995; 74:1459-67.

20. Magnusson 1, Lindhe J, Yoneyama T. Recolonization of subgingival microbiota fol/oming scaling in deep pockets. J Clin Periodonlol. 1984; 11:193-207.

21. Labandeira A, Ballesteros A. Truscello E, Lavandeira H. Desinfección total: otra alternativa para la terapia periodontal. Rev Asoc Odontol Arg, 2009; 97(4):311318.

22. Campideli Fonseca D, Cortelli JR, Cortelli SC, Miranda Cota LO, Machado Costa LC, Moreira Castro MV, Oliveira Azevedo AM, Costa FO. Clinical and microbiological evaluation of scaling and root planning per quadrant and one-stage full mouth disinfection associated with azithromycin or chlorhexidine: a clinical randomized controlled trial. J Periodontol. 2015 Aug 7:116.

23. Bollen CM, Vandekerckhove BN, Papaioannou W, Van Eldere J, Quirynen M. FuIl/-versus partial-mouth disinfection in treatment of periodontal infection. A pilot study. Long-term microbiological observations. J Clin Periodontol. 1996; 23:960- 70.

24. Koshy G, Kawashima Y. Effects of single-visit fullmouth ultrasonic debridement versus quadrant-wise ultrasonic debridement. J Clin Periodontol.2005;32:73443.

25. Sigusch BIN, Günlsch A, Pfitzner A. Enhanced root planing and systemic metronidazole administration improve clinical and microbiological outcomes in a two step treatment procedure. J Periodol. 2005; 76:991-7.

26. Bono A, Brunotto M. La amoxicilina / metronidazol o raspado y alisado radicular en el tratamiento de la periodontitis crónica. Acta Odontol Latinoam 2010; 23 (3): 196-203.

27. Eberhard J, Jepsen S, Jervøe-Storm PM, Needleman I, Worthington HV. Full-mouth disinfection for the treatment of adult chronic periodontitis. Cochrane Database Syst Rev. 2008 Jan 23;(1):CD004622. https://www.cochranelibrary.com/cdsr/doi/10.1002/1465 1858.CD004622.pub2/epdf/standard

28. Kinane DF, Papageorgakopoulos G. Full mouth disinfection versus quadrant debridement: the clinician's choice. J Int Acad Periodontol. 2008 Jan;10(1):6-9.

29. Moher D, Liberati A, Tetzlaff J, Altman DG, The PRISMA Group (2009). Preferred reporting items for systematic reviews and meta-analyses: the PRISMA statement. PLoS Med 6(7): e1000097. doi:10.1371/journal.pmed1000097

30. Deeks JJ, Higgins JPT. Statistical algorithms in Review Manager 5 on behalf of the statistical methods group of the Cochrane Collaboration. 2010. https://training.cochrane.org/handbook/statisticalmethods-revman5

31. Cooper $\mathrm{H}$ \& Hedges LV. The handbook of research synthesis. Newbury Park, CA: Russell Sage Foundation. 1994.

32. Sterne JAC, Egger M. Funnel plots for detecting bias in meta-analysis: Guidelines on choice of axis. J Clin Epidemiol. 2001; 54, 1046-1055.

33. Hugar SS, Patil S, Metgud R, Nanjwade B, Hugar SM. Influence of application of chlorhexidine gel and curcumin gel as an adjunct to scaling and root planing: A interventional study. J Nat SciBiol Med. 2016;7(2):14954

34. Killoy WJ . The use of locally delivered chlorhexidine in the treatment of periodontitis. Clinical results. J Clin Periodontol. 1998 Nov;25(11 Pt 2):953-8; discussion 978-9. 
35. Soskolne WA, Chajek T, Flashner H, Landau I, Stabholtz A, Kolatch B, Lerner EI. An in vivo study of the chlorhexidine release profile of the PerioChip in the gingival crevicular fluid, plasma and urine. J Clin Periodontol. 1998; 25 (12): 1017-1021

36. Jeffcoat MK, Bray KS, Ciancio SG, Dentino AR, comidas de DH, Gordon JM, Gunsolley JC, Killoy WJ, Lowenguth RA, Magnusson NI, Offenbacher S, Palcanis KG, Proskin HM, Finkelman RD, Flashner M. Adjunctive use of a subgingival controlled-release chlorhexidine chip reduces probing depth and improves attachment level compared with scaling and root planing alone. J Periodontol. 1998; 69 (9): 989-997

37. Paolantonio M, D'Angelo M, Grassi RF, Perinetti G, Piccolomini R, Pizzo G, Annunziata H, D'Archivio D, D'Ercole S, Nardi G, Guida L. Clinical and microbiologic effects of subgingival controlled-release delivery of chlorhexidine chip in the treatment of periodontitis: a multicenter study. J Periodontol. 2008; 79 (2): 271-282

38. Heasman PA, Heasman L, Stacey F, McCracken GI (2001) Local delivery of chlorhexidine gluconate (PerioChip) in periodontal maintenance patients. J Clin Periodontol 28 (1): 90-95

39. Dilsiz A, Canakci V, Aydin T. Clinical effects of potassium-titanyl-phosphate laser and photodynamic therapy on outcomes of treatment of chronic periodontitis: a randomized controlled clinical trial. J Periodontol. 2013 Mar;84(3):278-86.

40. Cheng Y, Chen JW, Ge MK, Zhou ZY, Yin X, Zou SJ. Efficacy of adjunctive laser in non-surgical periodontal treatment: a systematic review and meta-analysis. Lasers Med Sci. 2016;31(1):151-63.

41. Pradeep AR, Garg V, Kanoriya D, Singhal S. $1.2 \%$ Rosuvastatin versus $1.2 \%$ atorvastatin gel local drug delivery and redelivery in treatment of intrabony defects in chronic periodontitis: a randomized placebo-controlled clinical trial. J Periodontol. 2016;87(7):756-62.

42. Cosgarea R, Juncar R, Heumann C, Tristiu R, Lascu L, Arweiler N, Stavropoulos A, Sculean A. Non-surgical periodontal treatment in conjunction with 3 or 7 days systemic administration of amoxicillin and metronidazole in severe chronic periodontitis patients. A placebocontrolled randomized clinical study. J Clin Periodontol. 2016 Sep; 43 (9): 767-77.

43. Durand R. Adjunct local antimicrobials provide statistically significant benefits over subgingival debridement alone in patients with chronic periodontitis. J Am Dent Assoc. 2015; 146(5): 341 - 343.

44. Jose KA, Ambooken M, Mathew JJ, Issac AV, Kunju AP, Parameshwaran RA. Management of chronic periodontitis using chlorhexidine chip and diode laser-a clinical study. J Clin Diagn Res. 2016 Apr;10(4):ZC7680 .
45. Alwaeli HA, Al-Khateeb SN, Al-Sadi A. Long-term clinical effect of adjunctive antimicrobial photodynamic therapy in periodontal treatment: a randomized clinical trial. Lasers Med Sci. 2015 Feb;30(2):801-7.

46. Wiebe CB, Putnins EE. The periodontal disease classification system of the American Academy of Periodontology--an update. J Can Dent Assoc. 2000 Dec;66(11):594-7.

47. Pejčić A, Kojović D, Minić I, Mirković D, Denić M, Stojanović M. Therapeutic efficacy of clindamycin gel as an adjunct to scaling and root planing therapy in chronic periodontal disease. Acta Clin Croat. 2015 Mar;54(1):4651

48. Pradeep AR, Kumari M, Rao NS, Naik SB. $1 \%$ alendronate gel as local drug delivery in the treatment of Class II furcation defects: a randomized controlled clinical trial. J Periodontol. 2013 Mar;84(3):307-15.

49. Sharma Al, Pradeep AR. Clinical efficacy of $1 \%$ alendronate gel as a local drug delivery system in the treatment of chronic periodontitis: a randomized, controlled clinical trial. J Periodontol. 2012 Jan;83(1):118.

\author{
Corresponding to/Correspondencia a: \\ Dr. Alejandra Bono \\ Facultad de Odontología \\ Universidad Nacional de Córdoba \\ Haya de la Torre $s / n$. ciudad universitaria. \\ Córdoba Argentina. CP. 5000
}

E-mail/Correo electrónico: alejandrabono@hotmail.com 

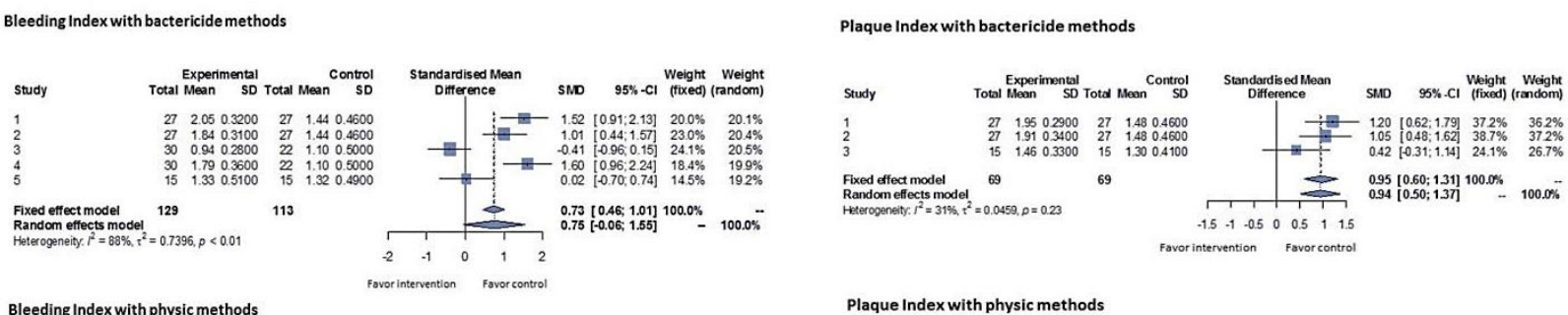

Bleeding Index with physic methods
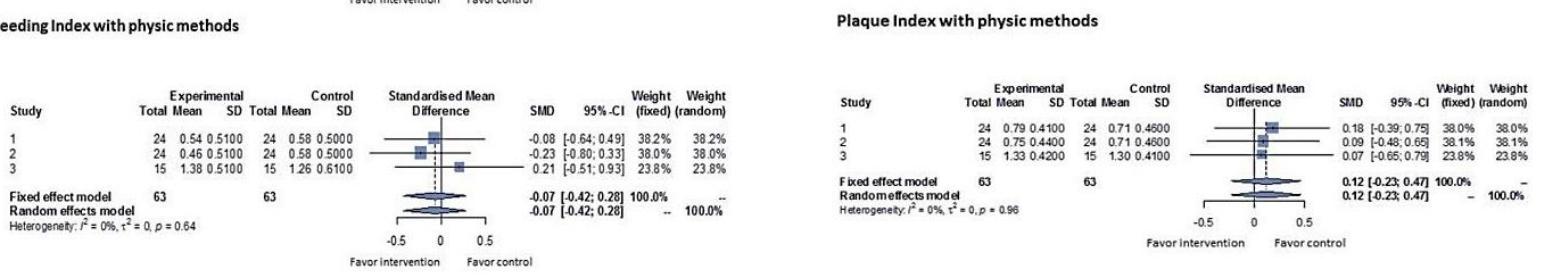

Probing Depth with bactericide methods

Clinical Attachment Loss with bactericide methods
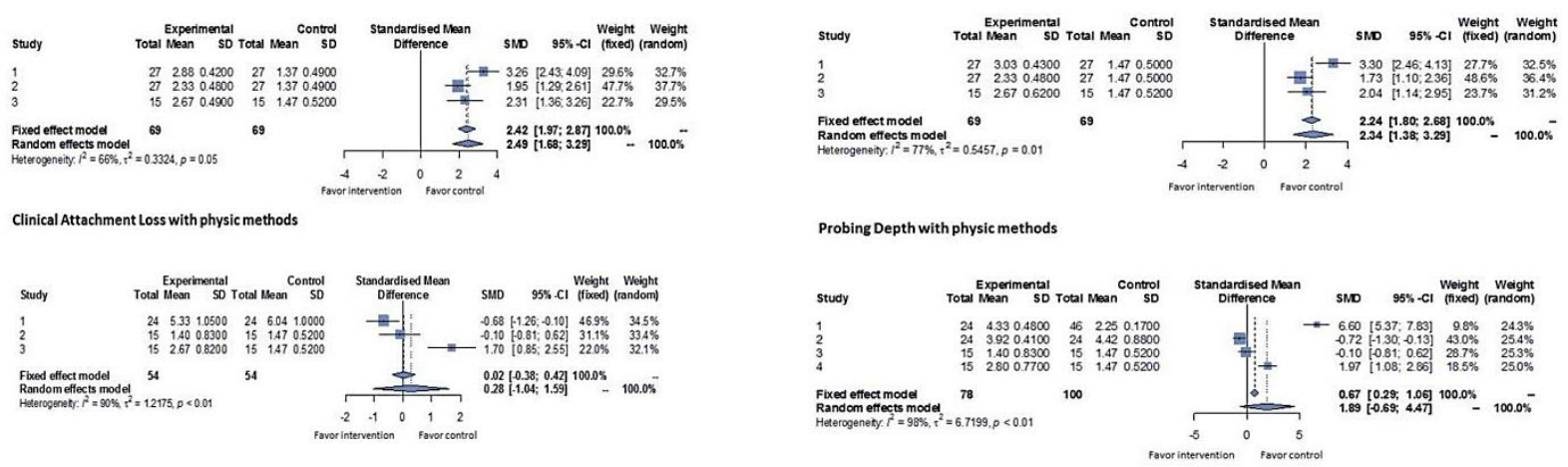

Figure 2. The effectiveness of different treatments on periodontitis. Bleeding Index : Bactericide method: Study 1: Pradeep et al.2016, Study 2 Pradeep et al.2016, Study 3: Hugar et al.2016; Study 4:Hugar et al.2016; Study 5: Kachapilly Arun et al. 2016; Physic method: Study 1: Bottini et al. 2017, Study 2: Bottini et al. 2017, Study 3:Kachapilly Arun et al. 2016; Plaque Index; Probing Depth and Clinical Attachment Loss: Bactericide method: Study 1: Pradeep et al.2016, Study 2: Bottini et al. 2017, Study 3:Kachapilly Arun et al. 2016; Physic method: Study 1: Pradeep et al.2016, Study 2: Bottini et al. 2017, Study 3:Kachapilly Arun et al. 2016 